\title{
ASPEK BIOLOGI DAN TINGKAT PEMANFAATAN UDANG DOGOL (Metapenaeus ensis) DI PERAIRAN MEULABOH
}

\author{
Hufiadi $^{\text {a* }}$ Ap’idatul Hasanah ${ }^{\mathrm{a}}$, dan Andina Ramadhani Putri Pane ${ }^{\mathrm{a}}$ \\ ${ }^{\mathrm{a}}$ Balai Riset Perikanan Laut, Cibinong-Bogor, Indonesia
}

*Koresponden penulis : Alamat email : hufiadibrpl@gmail.com

\begin{abstract}
Abstrak
Udang dogol (Metapenaeus ensis) merupakan salah satu komoditas udang yang ditangkap menggunakan alat tangkap pukat dasar di perairan Meulaboh. Diperlukan informasi ilmiah agar dapat dilakukan upaya pengelolaan sumberdaya udang dogol agar populasinya tetap terjaga dan lestari. Tujuan dari penelitian ini adalah mengetahui aspek biologi baik struktur ukuran, hubungan panjang karapas dengan bobot tubuh, rasio kelamin, tingkat kematangan gonad, perbandingan ukuran pertama kali tertangkap (Lc) dengan ukuran pertama kali matang gonad (Lm) serta tingkat pemanfaatannya di perairan Meulaboh. Penelitian dilakukan dari April sampai dengan Desember 2018 dengan sampel sebanyak 4.701 ekor baik jantan maupun betina. Struktur ukuran udang dogol 12 - $50 \mathrm{~mm}$ dengan dominan pada ukuran $30 \mathrm{~mm}$ dengan pola pertumbuhan allometrik negatif. Rasio kelamin udang seimbang antara jantan dengan betina dengan tingkat kematangan gonad tertinggi pada bulan September yang diprediksi sebagai puncak musim pemijahan. Ukuran pertama kali matang gonad (Lm) $25,95 \mathrm{~mm}$, udang dogol di perairan Meulaboh lebih dahulu matang gonad dari pada ukuran pertama kali tertangkap (Lm) 28,10 mm sehingga baik bagi lingkungan ( $\mathrm{Lm}>\mathrm{Lc}$ ). Tingkat pemanfaatan $(\mathrm{E})$ udang dogol masih rendah (E) 0,35 dan ini menunjukkan masih dapat dilakukan upaya peningkatan penangkapan dengan tidak menggunakan alat tangkap pukat dasar sesuai dengan Permen KP Nomor 2 Tahun 2015.
\end{abstract}

Kata kunci : aspek biologi, Meulaboh, tingkat pemanfaatan, udang dogol

\begin{abstract}
Endeavour shrimp (Metapenaeus ensis) is one of the shrimp commodities that is caught by using a basic trawler that is still operating in the waters of Meulaboh. For this reason, scientific information is needed to make efforts to manage endeavour shrimp resources so that the population is maintained and sustainable. The purpose of this research was to determine the biological aspects of both the size structure, the relationship between carapace length and body weight, sex ratio, gonad maturity level, comparison of the length at first capture (Lc) with the length at first maturity $(\mathrm{Lm})$ and the exploitation level in Meulaboh waters. The research was conducted from April to December 2018 with a sample of 4.701 samples, both male and female. Structure of endeavour shrimp size $12-50 \mathrm{~mm}$ with a dominant size $30 \mathrm{~mm}$ with allometric negative growth patterns. Sex ratio is balanced between males and females with the highest level of gonad maturity in September which is predicted to be the peak of the spawning season. The length at first maturity $(\mathrm{Lm})$ is $25,95 \mathrm{~mm}$ smaller than the length at first capture $(\mathrm{Lc}) 28,10 \mathrm{~mm}$ so that it good for the environment $(\mathrm{Lm}>\mathrm{Lc})$. Exploitation level $(E)$ is still low 0,35 and this shows that efforts to increase catching can still be done, supported by not using basic trawl fishing gear by Minister of Forestry Regulation KP Number 2 the Year 2015.
\end{abstract}

Keywords: biological aspects, endeavour shrimp, exploitation level, Meulaboh,

\section{PENDAHULUAN}

Wilayah Pengelolaan Perikanan (WPP) 572 NRI Samudera Hindia barat Sumatera berada pada posisi strategis karena merupakan bagian perairan Samudera Hindia yang berbatasan langsung dengan beberapa negara. Pengaruh dari Samudera Hindia tersebut menyebabkan perairan ini subur akan sumberdaya perikanan. Produktivitas perikanan Indonesia khususnya produksi udang di Indonesia dari tahun ke tahun terus meningkat pada tahun 2000 sebesar 7,4 \% (Direktorat Jendral Perikanan, 2000) dan potensi produksi udang tahun 2016 sampai 
2017 sebesar 11,31\% (Kementrian Kelautan dan Perikanan, 2018).

Meulaboh merupakan terletak di bagian Barat Sumatera dimana kondisi perikanan pukat cincin, payang, pancing, pukat dasar, jaring insang dan trammel net memberikan kontribusi terhadap perkembangan masyarakat nelayan setempat. Perikanan pukat cincin, pancing tonda dan payang merupakan alat tangkap yang penting dan berkonstribusi dalam mendaratkan ikan pelagis. Pancing ulur dan rawai dasar berkonstribusi dalam pemanfaatan perikanan demersal serta ikan karang. Sedangkan pukat dasar/ mini trawl dan trammel net berkonstribusi terutama dalam pemanfaatan perikanan udang.

Pemanfaatan sumberdaya udang di perairan Meulaboh, Aceh Barat umumnya dilakukan oleh usaha perikanan skala kecil/ tradisional. Hasil tangkapan pukat dasar (mini trawl) di PPS Ujong Baroh, Meulaboh didominasi oleh udang kelong (Penaeus indicus), rajungan (Portunus sanguilentus), kepiting (Scylla serrata), petek (Liognathus bindus), udang dogol (Metapenaeus ensis), udang krosok (Metapenaeus rosea), udang krosok (Solenassora subna), ende (Metapenaeus affinis), udang krosok (Metapenaeus brevicornis), udang krosok putih kecil (acetes spp.)gulama (Johnius macropterus), nomei (Harpadon nehereus), kuniran (Upeneus sulphureus), Cumi-cumi (Loligo spp), japuh (Dussumieria acuta), bloso (Saurida wanieso), sebelah (Psettodes erumei) dan layur (Trichiurus lepturus). Sedangkan perikanan trammel hasil tangkapan didominasi oleh udang kelong (Penaeus indicus), udang dogol (Metapenaeus ensis), kapas-kapas (Pentaprion longimanus), Bloso (Saurida wanieso), Layur (Trichiurus lepturus), kembung (Rastrelliger kanagurta), selar (Selar spp), dan kurisi (Nemipterus nemurus).

PPS Ujong Baroh merupakan lokasi pendaratan ikan dan udang elayan yang mayoritas menggunakan pukat dasar. Pada musim penangkapan udang dan kondisi cuaca yang memungkinkan untuk operasi penangkapan, nelayan Meulaboh selain mengoperasikan alat tangkap pukat dasar juga mengoperasikan jaring tiga lapis (trammel net). Nelayan melakukan operasi penanggkapan udang dalam satu trip selama 1- 2 hari di laut. Lokasi penangkapan relatif tidak jauh dari pantai umumnya untuk nelayan yang melakukan penangkapan harian (one day fishing) beroperasi di sekitar muara sungai $(3-4$ mil), sementara nelayan yang beroperasi dua hari melakukan penangkapan lebih ke tengah yaitu mencapai 6-8 mil dari pantai.

Besarnya permintaan udang memerlukan adanya informasi ilmiah dan data potensi sumberdaya udang yang lengkap, up to date, dan berkelanjutan dari perairan Meulaboh (Aceh Barat). Penelitian sebelumnya telah dilakukan di perairan yang sama tahun 2009 untuk udang kelong (Penaeus sp) [14] dan penelitian tentang udang dogol (Metapenaeus ensis) di perairan Cilacap dan di perairan Arafura [11]; [10], di perairan Selat Bangka [18], dan di perairan Binuangeun [9].

Aktivitas penangkapan pukat dasar dapat menjadikan tekanan eksploitasi sumberdaya udang di perairan Meulaboh (Aceh Barat). Pengelolaan yang disarankan adalah penggunaan alat tangkap yang ramah lingkungan tanpa merusak kondisi substrat dasar perairan yang berlumpur di mana terdapat banyak habitat penting bagi udang [12]. Untuk mendapatkan data dan informasi yang lebih lengkap dapat digunakan sebagai bahan dasar pengelolaan sumberdaya udang dan dapat di jadikan alternatif kebijakan, maka perlu dilakukan kajian yang konfrehensif mengenai aspek biologi dan tingkat pemanfaatannya.

\section{BAHAN DAN METODE}

Pengumpulan data sebaran frekuensi panjang karapas (carapace length) udang dari hasil tangkapan pukat dasar di perairan Meulaboh (Barat Sumatera) yang dilaksanakan selama 9 (sembilan) bulan dengan dibantu tenaga enumerator. Pengambilan sampel udang sebanyak 4.701 ekor, dilakukan pengamatan sampel setiap bulan meliputi pengukuran panjang karapas (CL), penimbangan bobot tubuh udang, pengamatan jenis kelamin dan tingkat kematangan gonad udang betina.

Lokasi penangkapan udang di Meulaboh berada di sekitar perairan pantai Barat Sumatra, tepatnya di Kecamatan Johan Pahlawan, Kuala Bubon dan Ihok Bubon (Samatiga), KualaTua dan Tandu (Nagan Raya), Suak Semaseh (Arongan Lambalek). Grid untuk lokasi penangkapan udang pada titik 3685, 3686, 3441 dan 3440. Daerah penangkapan udang di Meulaboh berada di sekitar perairan barat Sumatera pada kedalaman $10-20 \mathrm{~m}$. tepatnya di perairan Samudera Hindia. Letak daerah pendaratan 


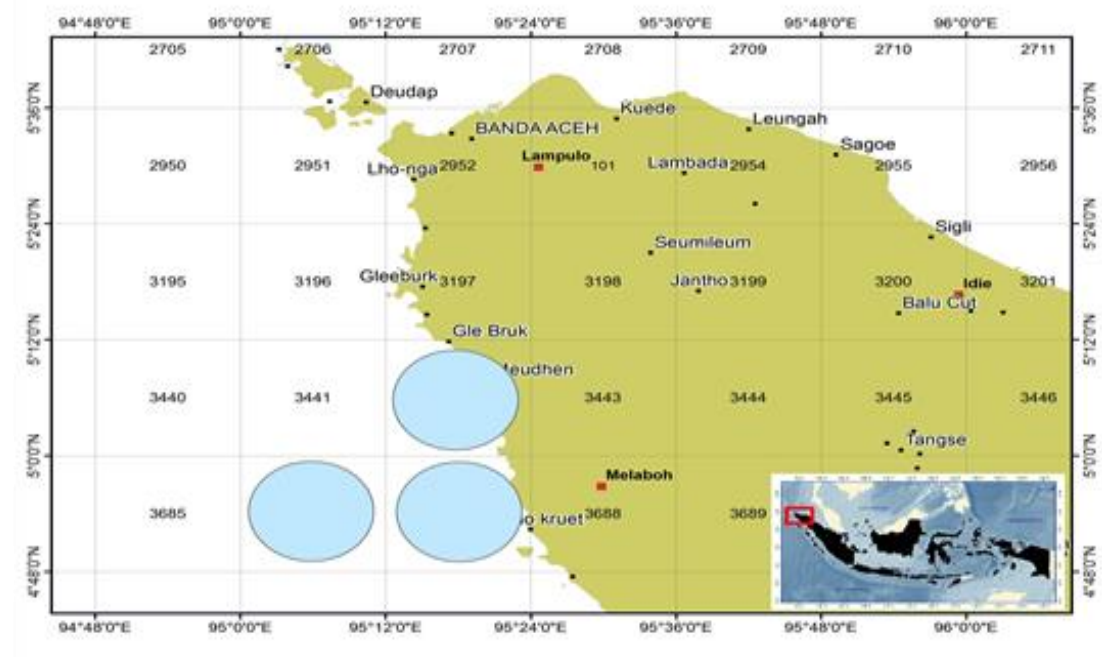

Gambar 1. Daerah penangkapan udang di perairan Meulaboh

\section{Analisis data}

Hubungan panjang karapas dengan bobot tubuh dianalisa menggunakan persamaan eksponensial [22]:

$\mathrm{W}=\mathrm{aL}^{\mathrm{b}}$

di mana :

$\mathrm{W} \quad=$ bobot individu udang $(\mathrm{g})$

$\mathrm{L} \quad=$ panjang karapas udang $(\mathrm{mm})$

$\mathrm{a}$ dan $\mathrm{b}=$ konstanta hasil regresi

Hubungan panjang karapas dengan bobot dapat dilihat dari nilai konstanta $b$, jika $b$ $=3$, maka hubungan bersifat isometrik (pertambahan panjang sebanding dengan pertumbuhan berat), jika $b \neq 3$, maka hubungan yang terbentuk adalah allometrik (pertambahan panjang tidak sebanding dengan pertambahan berat). Untuk menentukan bahwa nilai $\mathrm{b}=3$ atau $\mathrm{b} \neq 3$, maka digunakan uji $\mathrm{t}$ [23]. Selanjutnya $t_{\text {hit }}$ yang didapat akan dibandingkan dengan $\mathrm{t}_{\text {tabel }}$, maka terima $\mathrm{H}_{0}$.

\section{Tingkat kematangan gonad dan nisbah kelamin}

Pengambilan data tingkat kematangan gonad udang betina dilakukan dengan pengamatan secara morfologis (visual) dan membuka bagian cephalotorax atau karapas di bagian kepala udang. Penentuan TKG udang lobster mengacu dari hasil Silva \& Landim (2006).

Perhitungan nisbah kelamin di dasarkan pada persamaan [24] :
$\mathrm{NK}=\mathrm{Nbi} / \mathrm{Nji}$

di mana :

$\mathrm{NK}=$ nisbah kelamin

Nbi = jumlah udang betina pada kelompok ukuran ke-i

$\mathrm{Nji}=$ jumlah udang jantan kelompok ukuran ke-I serta dilakukan uji Chi Kuadrat [25].

\section{Ukuran ikan pertama kali tertangkap}

Ukuran ikan pertama kali tertangkap menggunakan sebaran frekuensi panjang ikan, kemudian dianalisis dengan menggunakan pendekatan [8], dimana kelas panjang yang mempunyai nilai panjang cagak (FL) atau panjang karapas (CL) tertinggi merupakan panjang ikan pertama kali tertangkap (Lc). Model matematika persamaan sebagai berikut :

$\mathrm{F}_{(\mathrm{c})}=(\mathrm{ndL} / \mathrm{s} \sqrt{2} 2 \pi)^{*} \mathrm{e}\left[-(\mathrm{L} "-\mathrm{L})^{2} / 2 \mathrm{~S}^{2}\right]$

Keterangan :

$\mathrm{F}_{(\mathrm{c})}=$ frekuensi ikan dalam kelas panjang

$\mathrm{n}=$ jumlah contoh dalam sampling

$\mathrm{dL}=$ interval kelas panjang

$\mathrm{s} \quad=$ standar deviasi

$\pi=$ konstanta 3,14

$\mathrm{L}$ ' = nilai tengah kelas panjang

$\mathrm{L}=$ rerata panjang satu kohort ikan

Selanjutnya pendugaan rerata dan standar deviasi panjang ikan dalam setiap 
contoh dilakukan dengan mengubah persamaan dalam bentuk linear sebagai berikut :

$\Delta \ln F_{c}(z)=a-b x(L+d L / 2)$

dimana :

$\Delta \ln \mathrm{F}_{\mathrm{c}}(\mathrm{z})=$ selisih logaritma dua kelas panjang

$\mathrm{L}+\mathrm{dL} / 2=$ batas atas masing-masing kelas panjang

$\mathrm{a}, \mathrm{b}=$ konstanta

Ukuran panjang ikan pertama kali tertangkap (Lc), ukuran ikan pertama kali matang gonad $(\mathrm{Lm})$, dan status pengusahaan berdasarkan beberapa parameter yakni perbandingan antara nilai Lc dan Lm [8], persentase ikan matang gonad yang tertangkap [1] dan rasio potensi pemijahanan [6].

\section{Ukuran ikan pertama kali matang gonad}

Penghitungan ukuran panjang karapas rata-rata matang gonad (Lm) menggunakan pendekatan fungsi logistik [26].

\section{Parameter pertumbuhan dan kematian}

Dugaan parameter pertumbuhan $\left(\mathrm{L}_{\infty}\right.$ dan $\mathrm{K})$, dan parameter kematian ikan (Z, M, dan F), diperoleh dengan menggunakan paket program FISAT [27].

Persamaan model von Bertalanffy :

$\mathrm{L}_{\mathrm{t}=} \mathrm{L}_{\infty \text {-eks }}\left(\mathrm{K}^{*}\left(\mathrm{t}-\mathrm{t}_{0}\right)\right.$

di mana :

$\mathrm{L}_{\mathrm{t}}=$ panjang ikan pada umur $\mathrm{t}$

$\mathrm{L}_{\infty}=$ rata-rata panjang maksimum

$\mathrm{K}=$ konstanta pertumbuhan

$\mathrm{t}_{0} \quad=$ umur pada panjang $0 \mathrm{~cm}$

Frekuensi panjang bulanan dianalisis secara langsung dengan program ELEFAN 1. Sebaran jumlah udang menurut kelompok panjang karapas diperoleh dari pengambilan contoh hasil tangkapan polymodal. Modusmodus atau pucak pucak teridentifikasi dengan proses restrukturisasi. Puncak puncak tersebut diasumsikan mewakili kohor-kohor dan paling cocok dalam pembentukan suatu kurva pertumbuhan von Bertalanffy secara interaktif, nilai-nilai $\mathrm{L}_{\infty}$ dan $\mathrm{K}$ dari $\mathrm{Rn}$ yang tertinggi.

Kematian total (Z) diperoleh dari analisis kurva penangkapan yang dikonversikan ke panjang (length converted catch curve). Analisa ini menggunakan data frekunsi panjang karapas dan $\mathrm{L}_{\infty}$ dan $\mathrm{K}$ sebagai data yang di input. Setelah kurva terbentuk dipilih data panjang karapas yang terkena eksploitasi, untuk dianalisis(regresi) menghasilkan Z(-b).

Kematian alami (M) diduga dengan rumus empiris [5] dan [8] :

$M=\operatorname{Exp}\left(-0,0152-0,279 * L_{n} L_{\infty}+0,6543 * L_{n}\right.$ $\left.\mathrm{K}+0,463 * \mathrm{~L}_{\mathrm{n}} \mathrm{T}\right)$

$\mathrm{T}=$ suhu perairan dari survei laut di daerah penangkapan $29^{\circ} \mathrm{C}$ dimasukan sebagai input. Kematian karena penangkapan (F) diperoleh dari nilai $Z$ dikurangi $M$, sedangkan dugaan tingkat pemanfaatan (E) dari F dibagi $Z$.

\section{HASIL DAN BAHASAN}

\section{Kisaran ukuran}

Ukuran udang yang tertangkap berkisar antara $12-50 \mathrm{~mm}$ dengan modus tertinggi pada ukuran $30 \mathrm{~mm}$ dan rata-rata kisaran ukuran setiap bulan disajikan pada Tabel 1 dan frekuensi udang tertangkap pada gambar 2 . Ukuran udang di perairan ini masih lebih besar dibandingkan di perairan Tanah Laut, Kalimantan Selatan yaitu berkisar antara 10-40 $\mathrm{mm}$ dengan ukuran udang betina cenderung lebih panjang dibandingkan udang jantan [15]. Penyebab udang tertangkap berukuran lebih kecil adalah karena ditangkap pada perairan dangkal dan biasanya berjenis kelamin jantan. 
Tabel 1. Struktur ukuran udang dogol di Meulaboh

\begin{tabular}{lcccc}
\multicolumn{1}{c}{ Bulan } & Ekor $(\mathbf{n})$ & Ukuran $(\mathbf{m m})$ & Modus Jantan $(\mathbf{m m})$ & Modus Betina $(\mathbf{m m})$ \\
April & 531 & $12-32$ & 20 & 30 \\
Mei & 527 & $16-44$ & 20 & 28 \\
Juni & 284 & $16-40$ & 20 & 26 \\
Juli & 638 & $16-46$ & 20 & 28 \\
Agustus & 374 & $16-44$ & 16 & 32 \\
September & 396 & $20-50$ & 24 & 36 \\
Oktober & 824 & $18-44$ & 26 & 32 \\
November & 796 & $18-46$ & 30 & 34 \\
Desember & 331 & $16-46$ & 26 & 28 \\
\hline
\end{tabular}

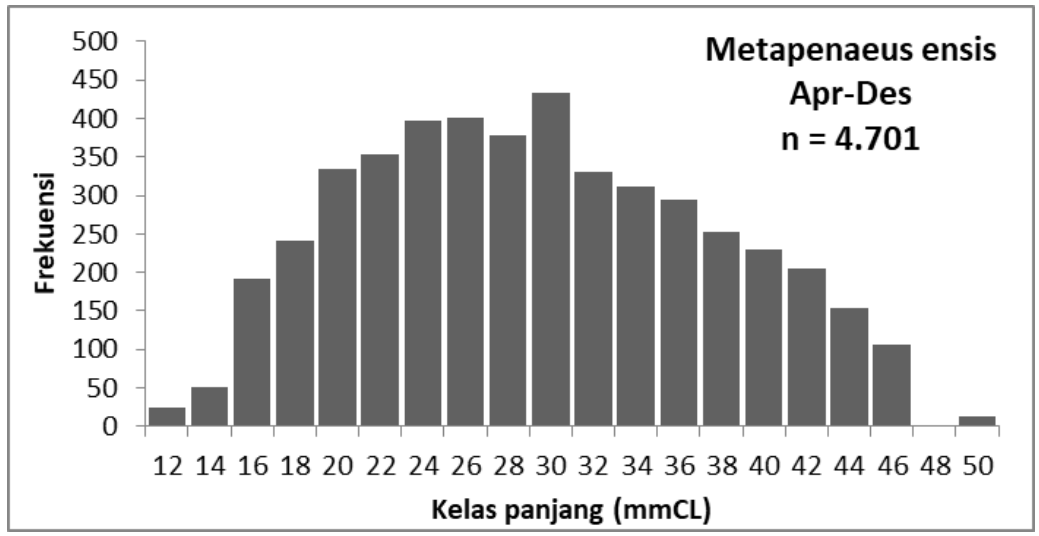

Gambar 2. Frekuensi udang dogol (Metapenaeus ensis) di perairan Meulaboh

\section{Hubungan panjang berat}

Hubungan panjang berat udang dogol ini menunjukkan sifat pertumbuhan allometrik negatif dengan nilai $a=0,005, b=2,387$ dengan $\mathrm{R}^{2}=0,945$. Kondisi tersebut menunjukkan bahwa pertumbuhan panjang udang dogol lebih cepat dibandingkan dengan beratnya. Hasil ini selaras dengan penelitian di perairan

\section{Rasio kelamin}

Rasio kelamin udang dogol (Metapenaeus ensis) berdasarkan analisis chisquare menunjukkan kondisi seimbang atau menunjukkan perbandingan 1:1. Kondisi berbeda ditemukan di perairan Binuangeun dan Cilacap yaitu udang betina lebih dominan dibanding jantan [9]; [21]. Kondisi seimbang ataupun tidak seimbang antara jantan dan betina pada krustasea terjadi karena bermacam-macam faktor aitu perbedaan aktifitas makan, sex reversal, migrasi, dan perbedaan laju pertumbuhan [13]. Kondisi dimana dominannya udang betina ini mengindikasikan bahwa pembaruan populasi
Cilacap, di Arafura dan di Tanah Laut [11] ; [10] ; [15]. Penyebab perbedaan sifat pertumbuhan karena dipengaruhi makanan, individu, jenis kelamin serta lingkungan habitatnya. Menurut [19] bahwa udang jenis adalah merupakan omnivora yang dominan makanannnya adalah krustasea, detritus dan moluska.

(recovery) masih berjalan dengan baik dan dengan demikian status pemanfaatan sumberdaya udang di perairan Meulaboh terindikasi berada dalam tahapan yang berkelanjutan. Menurut [16] dan [17] bahwa jika perairan tersebut normal maka rasio kelamin jantan dan betina adalah seimbang. [4] menyatakan bahwa apabila udang betina dominan maka tekanan penangkapan yang tidak begitu tinggi, namun jika udang jantan yang dominan maka dapat menjadi indikasi bahwa tekanan penangkapan tinggi dan akan dapat mengurangi jumlah populasi udang dimasa mendatang. 


\section{Tingkat kematangan gonad}

Pengamatan terhadap tingkat kematangan gonad udang dogol (Metapenaeus ensis) betina di perairan Meulaboh menunjukkan udang yang belum matang sebesar 76,59\% dan yang sudah matang gonad sebesar 23,40\%. Udang dogol matang gonad dengan presentase tertinggi diperoleh pada bulan September (Gambar 3). Maka dapat diperkirakan bahwa puncak musim pemijahan udang terjadi pada bulan September dan ini berbeda dengan perairan Tanah Laut yang terjadi antara Maret - April serta di Selat Bangka pada bulan Juli [15]; [18]. Maka berdasarkan data tersebut diperkirakan bahwa udang ini tertangkap pada daerah pembesaran karena masih banyak yang belum matang gonad. Menurut [4] dan [20] bahwa udang muda (juvenile) hidup di daerah estuaria dibagian dasar perairan namun akan beruaya ke laut lebih dewasa dan jika akan memijah.

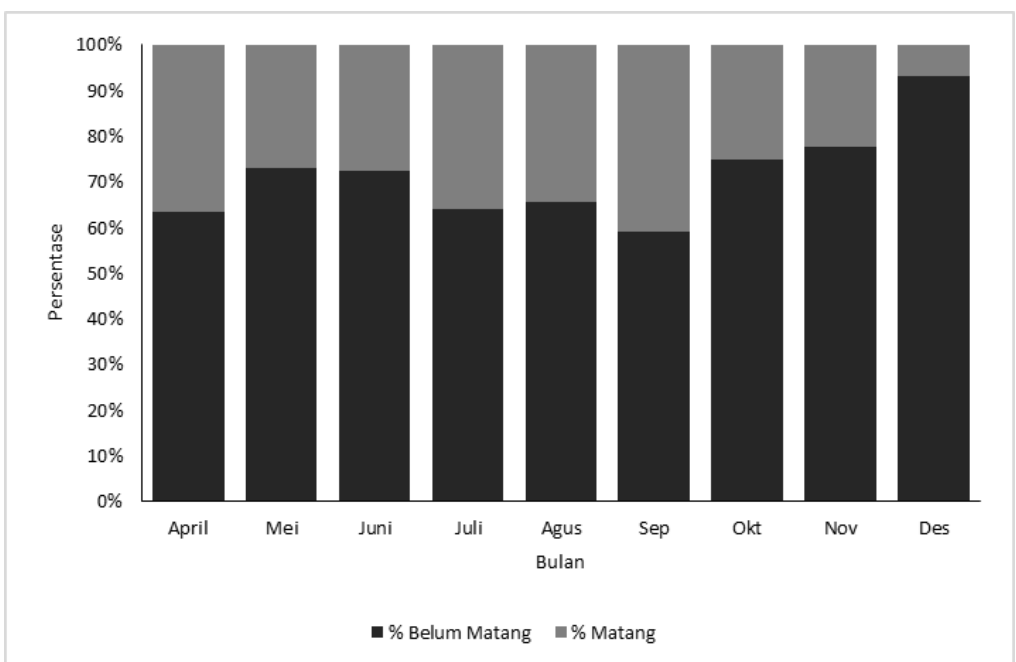

Gambar 3. Tingkat Kematangan Udang Dogol (Metapenaeus ensis) di Meulaboh

Panjang pertama kali tertangkap (Lc) dan panjang pertama kali matang gonad (Lm)

Rata-rata ukuran udang dogol (Metapenaeus ensis) yang tertangkap di Perairan Meulaboh pertama kali matang gonad (Lm) di ukuran 25,95 mmCL (Gambar 4) nilai SL-50 diperoleh nilai SL-50 28,10 mmCL.Nilai Lc lebih rendah dibandingkan nilai $\mathrm{Lm}$ 25,95 mmCL menunjukkan bahwa rata-rata udang dogol yang tertangkap di perairan Meulaboh adalah udang yang sudah matang gonad. Hal ini selaras dengan perairan Tanah Laut namun berbeda dengan kondisi di perairan Binuangeun dan Selat Bangka bahwa udang lebih dahulu tertangkap sebelum mengalami kematangan gonad [15]; [18]; [9]. Untuk itu kondisi penangkapan di perairan Meulaboh harus tetap di pertahankan agar stok udang tetap lestari.

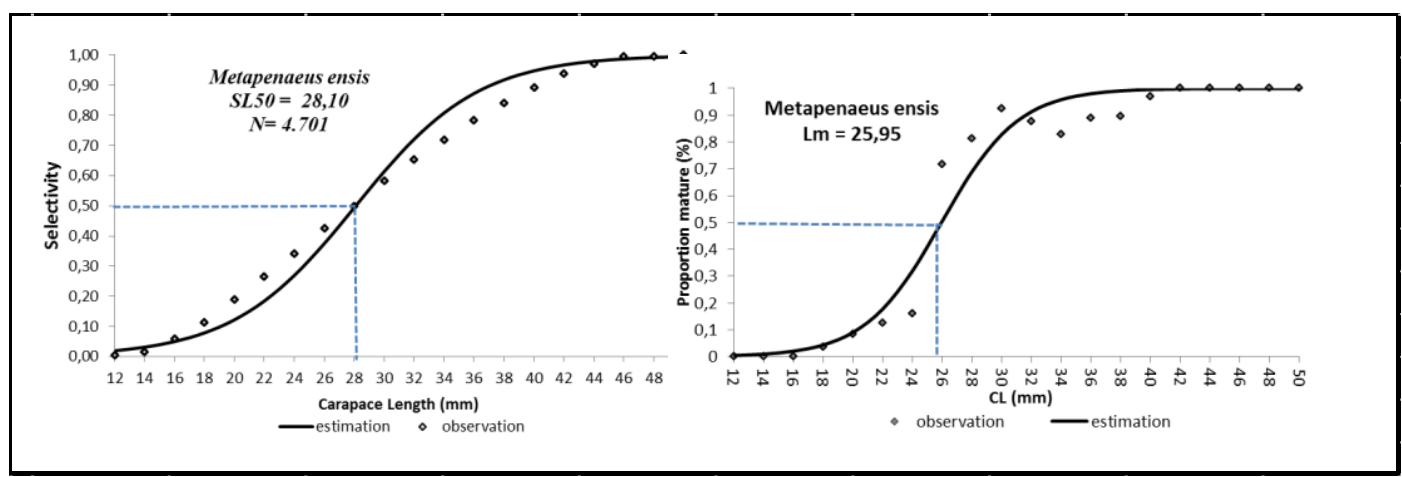

Gambar 4. Rata-rata ukuran pertama kali tertangkap (Lc) dan Rata-rata ukuran pertama kali matang gonad (Lm) Udang dogol (Metapenaeus ensis) di Meulaboh

Keberlanjutan sumberdaya ikan bertujuan untuk menangkap ikan pada ukuran yang sudah mencapai panjang optimum sehingga ikan ikan dewasa berkontribusi 
terlebih dahulu terhadap lingkungan baru tertangkap. Salah satu petunjuk bahwa sumberdaya ikan sudah dikelola dengan baik apabila rerata ukuran ikan pertama kali tertangkap sama atau lebih besar dari ukuran ikan pertama matang gonad ( $\mathrm{Lc} \geq \mathrm{Lm}$ ), hal ini dimasudkan untuk menghindari terjadinya recruitmen overfishing dan growth overfishing pada stok ikan (Walter et.al 2004). Jika sebagian dari hasil tangkapan yang diperoleh merupakan ukuran ikan yang belum dewasa merupakan kondisi yang sangat memprihatinkan. Oleh sebab itu kegiatan penangkapan harus selektif terhadap ukuran ikan atau udang untuk menghindari terjadinya rekruitmen overfishing dan growth overfishing pada stok ikan ataupun udang. Kondisi pengelolaan sumberdaya udang atau ikan yang kurang baik dapat mengakibatkan pertumbuhan stok ikan yang tidak sehat sebagai akibat tekanan penangkapan. Kondisi ini dapat diminimalisir dengan menangkap ikan pada ukuran yang sudah dewasa dan sudah mencapai panjang optimum, tetapi hal ini tentunya menjadi sebuah tantangan bagi pemangku kepentingan

dalam mengimplementasikannya [7].

\section{Laju kematian dan tingkat pemanfaatan}

Dengan menggunakan parameter pertumbuhan udang dogol yang telah dihitung $\left(\mathrm{K}=1,01\right.$ per tahun, $\mathrm{L}_{\infty}=52,63 \mathrm{~mm}$ sebagai bahan masukan untuk membuat kurva hasil tangkap, diperoleh nilai dugaan $\mathrm{Z}$ untuk udang dogol adalah 2,39 (Tabel 2). Nilai dugaan laju kematian alamiah (M) udang dogol sebesar 1,56 per tahun. Nilai dugaan laju kematian karena penangkapan $(\mathrm{F})$ dihitung dengan menggunakan persamaan: $\mathrm{F}=\mathrm{Z}-\mathrm{M}$ dan diperoleh hasil sebesar 0,83 per tahun. Dengan demikian nilai dugaan laju kematian karena penangkapan lebih besar dibandingkan dengan laju kematian alaminya.

Tingkat pemanfaatan (E) udang dogol adalah 0,35. Hal itu menunjukkan bahwa tingkat pemanfaatannya tidak mengarah pada kondisi lebih tangkap (over fishing). Kondisi tersebut perlu dipertahankan dan pengawsan dalam melakukan pemanfaatan.

Tabel 2. Parameter Populasi Udang Dogol di Meulaboh

\begin{tabular}{ccccccc}
$\mathbf{K}$ (pertahun) & $\mathbf{C L} \infty(\mathbf{m m})$ & $\mathbf{t}_{\mathbf{0}}$ & $\mathbf{Z}$ (pertahun) & $\mathbf{M}$ (pertahun) & $\mathbf{F}$ (pertahun) & $\mathbf{E}(\%)$ \\
1,01 & 52,63 & $-0,137$ & 2,39 & 1,56 & 0,83 & 0,35 \\
\hline
\end{tabular}

Laju pertumbuhan udang dogol pada penelitian ini sebesar 1,06 per tahun, hasil ini menunjukkan bahwa pertumbuhan udang dogol yang lebih cepat daripada udang dogol di perairan Cilacap dan Arafura [11]; [10]. Pertumbuhan yang cepat juga menunjukkan bahwa umur udang pendek dengan laju kematian yang cukup tinggi [3]. Laju pertumbuhan $(\mathrm{K})$ menunjukkan nilai lebih dari satu menunjjukan udang memiliki pertumbuhan yang cepat [2]; [4].

Parameter kematian total (Z) 2,39, Kematian Alamiah (M) 1,56, kematian karena penagkapan $(\mathrm{F}) 0,83$, dan tingkat pemanfaatan (E) 0,35 udang dogol (Metapenius ensis) di perairan Meulaboh relatif rendah dibandingkan dengan nilai-nilai $\mathrm{Z}, \mathrm{M}, \mathrm{F}$, dan $\mathrm{E}$ di perairan Arafura, Z senilai 4,79, M sebesar 1,88, F sebesar 2,9, dan E sebesar 0,61 [10]. Nilai $F$ menunjukkan seberapa besar dan meningkatnya tekanan penangkapan (fishing pressure) terhadap stok ikan di suatu perairan [28].

Parameter kematian total di perairan Meulaboh juga lebih rendah di bandingkan di perairan Cilacap, Madura, dan Aceh Timur
[11]; [5]; [29]. Hal ini menunjukkan kondisi di perairan-perairan tersebut telah mengalami tekanan penangkapan kecuali di perairan Meulaboh di mana tingkat pemanfaatannya masih rendah kondisi ini di duga karena nelayan di perairan Meulaboh memilih spot penangkapan yang banyak tertangkap udang windu atau tiger yang lebih ekonomis atau lebih mahal harganya di bandingkan udang dogol.

\section{KESIMPULAN DAN SARAN}

Struktur ukuran udang dogol (Metapenaeus ensis) di Meulaboh berukuran 12 - $50 \mathrm{~mm}$ dengan pola pertumbuhan allometrik negatif. Rasio kelamin jantan dan betina seimbang dengan perkiraan musim pemijahan pada bulan September. Ukuran pertama kali tertangkap (Lc) lebih besar daripada ukuran pertama kali matang gonad (Lm), artinya udang telah lebih dahulu memijah baru kemudian tertangkap. Tingkat kematian udang secara alami (M) lebih besar dibandingkan kematian akibat penangkapan (F) dengan tingkat pemanfaatan 0,35 , artinya 
ukuran mata jaring trammelnet yang digunakan dalam menangkap udang dengan ukuran udang pertama kali tertangkap.

Pengelolan sumberdaya udang di perairan Melaboh harus dipertahankan dengan baik dan tetap terjaga kelestariannya, namun secara bertahap juga perlu mengurangi penangkapan udang dengan menggunakan alat tangkap yang tidak ramah lingkungans (pukat dasar). Kondisi tingkat pemanfaatan udang dogol yang masih rendah dapat dilakukan upaya peningkatan pemanfaatan baik armada alat tangkap yang ramah lingkungan yaitu trammel net.

\section{PERSANTUNAN}

Tulisan ini merupakan kotribusi dari kegiatan hasil Penelitian Karakteristik Biologi Perikanan, Habitat Sumber Daya dan Potensi Produksi Sumber Daya Ikan di WPP 572, Balai Riset Perikanan Laut Cibonong, Jawa Barat. Penulis pertama, kedua dan selanjutnya merupakan kontributor utama dari tulisan ini.

\section{DAFTAR PUSTAKA}

[1] R. Froese, "Keep it simple: three indicators to deal with overfishing," Fish and Fisheries, vol. 5, hal. 86-91, 2003.

[2] J.A. Gulland, "Fish Stock Assessment," A manual of basic methods. FAO/Wiley Series. Rome, 223 p, 1983.

[3] D.D. Kembaren, dan E. Nurdin, "Dinamika Populasi dan Tingkat Pemanfaatan Udang Windu (Penaeus monodon) di Perairan Tarakan, Kalimantan Timur," Jurnal Penelitian Perikanan Indonesia, vol. 19, no. 4, hal. 221-226, 2013.

[4] N. Naamin, "Dinamika populasi udang jerbung (Penaeus merguiensis de Man) di perairan Arafura dan alternatif pengelolaannya," Disertasi Doktor pada Fakultas Pasca Sarjana, IPB Bogor, 381 p, 1984.

[5] D. Pauly, J. Ingles, dan R. Neal. "Application to shrimp stocks of objective methods for the estimation of growth, mortality, and recruitment related parameters from length frequency data (ELEFAN I and II)," In: Penaeid shrimp-their biology and management, Fishing News Book Limited. Farnham-Surrey-England, hal. 220-234, 1984.

[6] J. A. Prince, "Technical report on an SPR size assessment of the blue swimmer crab fishery in Southeast Sulawesi," Technical Report for IMACS, USAID, 30 pp Pauly, D (1984). Fish Population Dynamics in tropical Waters : A Manual for Use with Programmable Calculators. ICLARM Studies and Reviews, no. 8, 325 p, 2014.

[7] R. Saranga, S. Slmau, dan J. Kalesaran, "Ukuran Pertama Kali Tertangkap, Ukuran Pertama Kali Matang Gonad Dan Status Pengusahaan Selar boops Di Perairan Bitung," Journal of Fisheries and Marine Research, vol. 3, no. 1, hal. 67-74, 2019.

[8] P. Sparre, dan S. C. Venema, "Introduction to Tropical Fish Stock Assessment," Part I: Manual. FAO Computerized Information Series (Fisheries). FAO (Food and Agriculture Organization of the United Nations), $438 \mathrm{p}, 1999$.

[9] A. Suman, Prihatiningsih, P. Lestari, dan Pane A. P. R, "Population Parameter of Endeavour Shrimp (Metapenaeus ensis de Haan) in Binuangeun and Adjacent waters, West Java, Indonesia Fisheries Research Journal (IFRJ)," vol. 25, no. 1, hal $19-26,2019$.

[10] A. Suman, B. I. Prisantoso, dan D. D. Kembaren, "Parameter Populasi Udang Dogol (Metapenaeus ensis) Dan Udang Windu (Penaeus monodon) Di Laut Arafura," BAWAL, vol. 9 no.1, hal. 5762, 2017.

[11] A. Suman, "Pola Pemanfaatan Sumber Daa Udang Dogol (Metapenaeus ensis de Haan) di Perairan Cilacap dan Sekitarnya,". Disertasi. Pascasarjana Institut Pertanian Bogor, 2004.

[12] Tirtadanu, Suprapto, dan A. Suman, "Sebaran Frekuensi Panjang Hubungan Panjang Berat, Tingkat Kematangan 
Gonad dan rata-rata ukuran pertama kali Matang Gonad Udang Putih (Penaeus merguiensis De Man, 1888) Di Perairan Kotabaru, Kalimantan Selatan," $B A W A L$, vol 9, no. 3, hal 145-152, 2017.

[13] A. M. Wanner, "Sex ratio as a function of size in Marine Crustacea," American Nature, 106, hal. 321-351, 1972.

[14] Wedjatmiko, "Hasil Tangkapan Dan Aspek Biologi Udang Kelong (Penaeus.sp) Di Perairan Barat Aceh," Jurnal Penelitian Perikanan Indonesia, vol. 15, no. 2 (2009), hal. 133-140, 2019.

[15] A. Hasanah, A. Suman dan T. Ernawati. Beberapa aspek biologi udang dogol (Metapenaeus ensis) di perairan Tanah Laut, Kalimantan Selatan. Prosiding Simposium Nasional Krustasea 2017. 1521.2017

[16] Effendie, M.I. Biologi Perikanan. Yayasan Pustaka Nusantama. Yogyakarta, (1997) 8, 97-100.

[17] Darmono. Budidaya Udang Penaeus. Kanisius Yogyakarta, (1991). hlm. 35.

[18] P, Lestari, Tirtadanu, Kembaren, D, D dan Wedjatmiko. Parameter populasi udangdogol (Metapenaeus ensis Se haan, 1984) di Selat Bangka, Sumatera Selatan. Bawal. Vol 10, No 2 (2018).135-143. 2018

[19] A. A. Sentosa, Hedianto, D.A dan Suryandari, A. Kebiasaan makanan dan interaksi trofik komunitas udang penaeid di Perairan Aceh Timur. Bawal. Vol 9 No, 3 (2017). 197-206.

[20] Dall, W, Hill, J, Rothlisberg, P.C. dan Sharples, D.J. The Biology of Penaeidae In Advances in Marine Biology, Volume 27. (1990). Blaxter J.H.S. and Southward A.J. (Eds). Academic Press, New York. Pp $80: 283-288$
[21] Saputra, W. S, Solichin, A dan Rizkiyana. Keragaman jenis dan beberapa aspek biologi udang metapenaeus di perairan Cilacap, Jawa Tengah. Journal of management of aquatic resources. Vol 2 No 3 (2013). 37-46. 2013.

[22] Ball, D.V. \&, and Rao, K.V. "Marine Fisheries." New Delhi: Tata Mc. GrawHill Publishing Company Limited., 5-24 pp. 1984

[23] Walpole, Introduction to Statistics, Mc Millan, London.1990.

[24] M. K. Moosa dan I. Aswandi. Udang karang (Panulirus spp.) dari perairan Indonesia. Proyek Studi Potensi Sumberdaya Alam Indonesia, Studi Potensi Sumberdaya Ikan. Lembaga Oseanologi Nasional, LIPI, Jakarta: 123. 1984

[25] Steel, Robert G.D \& Torrie, James H. Prinsip dan Prosedur Statistika, Edisi Kedua. PT.Gramedia. Jakarta. 1989.

[26] M. King. Fisheries biology, assessment and management. Fishing News Books. A Division of Blackwell Science Ltd. London.Pinheiro, A. P. \& J. E. Lins

[27] Gayanilo FCJr., Sparre P., Pauly D., FAOICLARM Stock Assessment Tools (FiSAT) user's Guide (p. 126) FAO Computerised Information Series (Fisheries) No. 8 FAO. Rome. 1996

[28] A. Suman dan Boer M. Ukuran pertama kali matang kelamin, musim pemijahan dan parameter pertumbuhan udang dogol (Metapenaeus ensis de Hann) di perairan Cilacap dan sekitarnya. JPPI 11(2):69-74. 2005

[29] D. A. Hedianto, Suryandari A dan Thahjo D, W, H. Dinamika populasi dan status pemanfaatan udang windu penaeus monodon (fabricus, 1789) di perairan Aceh Timur, Provinsi Aceh. Jurnal Penelitian Perikanan Indonesia. Vol 22 No. 2. 71-82. 2016. 